\title{
Characterization of Magnetic Nanoparticles Coated with Chitosan: A Potential Approach for Enzyme Immobilization
}

\author{
Azariel Díaz-Hernández, ${ }^{1}$ Jorge Gracida, ${ }^{2}$ Blanca E. García-Almendárez $\left(\mathbb{D},{ }^{1}\right.$ \\ Carlos Regalado ${ }^{D},{ }^{1}$ Rosario Núñez, ${ }^{3}$ and Aldo Amaro-Reyes $\mathbb{D}^{1}$ \\ ${ }^{1}$ DIPA, PROPAC, Facultad de Química, Universidad Autónoma de Querétaro, Santiago de Querétaro, 76010 QRO, Mexico \\ ${ }^{2}$ Facultad de Química, Universidad Autónoma de Querétaro, Santiago de Querétaro, 76010 QRO, Mexico \\ ${ }^{3}$ Inorganic Materials and Catalysis Laboratory, Institut de Ciència de Materials de Barcelona (ICMAB-CSIC), Bellaterra, \\ 08193 Barcelona, Spain
}

Correspondence should be addressed to Aldo Amaro-Reyes; aldo.amaro@uaq.edu.mx

Received 8 March 2018; Accepted 29 May 2018; Published 4 July 2018

Academic Editor: Paulo Cesar Morais

Copyright (C) 2018 Azariel Díaz-Hernández et al. This is an open access article distributed under the Creative Commons Attribution License, which permits unrestricted use, distribution, and reproduction in any medium, provided the original work is properly cited.

\begin{abstract}
Cross-linking of magnetic nanoparticles with proteins plays a significant role in the preparation of new materials for biotechnological applications. The aim was the maximization of the magnetic mass attracted and protein loading of magnetic iron oxide nanoparticles coated with chitosan, synthesized in a single step by alkaline precipitation. Chitosan-coated magnetite particles $\left(\mathrm{Fe}_{3} \mathrm{O}_{4} @\right.$ Chitosan) were cross-linked to a xylanase and a cellulase $\left(\mathrm{Fe}_{3} \mathrm{O}_{4} @\right.$ Chitosan@Proteins), showing a 93\% of the magnetic saturation of the magnetite. X-ray diffraction pattern in composites corresponds to magnetite. Thermogravimetry and differential scanning calorimetry showed that $162 \mathrm{mg}$ of chitosan was coating one gram of composite and $12 \mathrm{mg}$ of protein was cross-linked to each gram of magnetic support. Cross-linking between enzymes and $\mathrm{Fe}_{3} \mathrm{O}_{4} @$ Chitosan was confirmed by infrared spectroscopy with Fourier transform, X-ray energy, and X-ray photoelectron spectroscopy dispersion analysis. From dynamic light scattering, transmission and electron microscopy the average particle size distribution was $230 \mathrm{~nm}$ and $430 \mathrm{~nm}$ for $\mathrm{Fe}_{3} \mathrm{O}_{4} @$ Chitosan and $\mathrm{Fe}_{3} \mathrm{O}_{4} @$ Chitosan@Proteins, showing agglomerates of individual spherical particles, with an average diameter of $8.5 \mathrm{~nm}$ and $10.8 \mathrm{~nm}$, respectively. The preparation method plays a key role in determining the particle size and shape, size distribution, surface chemistry, and, therefore, the applications of the superparamagnetic nanoparticles.
\end{abstract}

\section{Introduction}

Magnetic nanoparticles (MNP) have been extensively studied because of their biotechnological applications, especially biomedical and protein/enzyme immobilization [1]. MNP are composed of magnetic elements (iron, nickel, or cobalt) and their oxides, that is, magnetite $\left(\mathrm{Fe}_{3} \mathrm{O}_{4}\right)$, maghemite $\left(\gamma-\mathrm{Fe}_{2} \mathrm{O}_{3}\right)$, and cobalt ferrite $\left(\mathrm{CoFe}_{2} \mathrm{O}_{4}\right)$ [2]. Amid all varieties, superparamagnetic nanoparticles of $\mathrm{Fe}_{3} \mathrm{O}_{4}$ are the most commonly used iron oxides due to biocompatibility, low toxicity (can be used safely in humans if the concentrations are maintained below $100 \mathrm{mg} / \mathrm{mL}$ ), favorable magnetic properties, and null retention of residual magnetism [3, 4]. However, $\mathrm{Fe}_{3} \mathrm{O}_{4}$ and $\gamma$ - $\mathrm{Fe}_{2} \mathrm{O}_{3}$ can easily be air oxidized, losing their magnetic property [5]. This issue can be solved by coating the surface with artificial (polyethylene, polyvinylpyrrolidone, polyethylene glycol, polyvinyl alcohol, etc.) or natural (dextran, amylopectin, chitosan, etc.) materials. Besides, the incorporation of MNP into a chitosan network may improve its biocompatibility making the resultant nanoparticles suitable for biomedical applications such as protein immobilization, drug delivery systems, wound healing, tissue engineering, and magnetic resonance imaging [6]. Many enzymes that have a great deal of industrial potential require the application of genetic engineering techniques in order to improve their production. However, the production of recombinant enzymes is often expensive, with the enzymes being generally unstable and sensitive to changes in process conditions such as $\mathrm{pH}$, temperature, and substrate concentrations [7]. These limitations can be minimized 
or even eliminated with enzyme immobilization [8]. Covalent binding of enzymes on coated magnetic nanoparticle carriers provides strong linkages between the enzyme and carrier, enzyme leaching in aqueous media is minimized, and no protein contamination of the product occurs [9]. Moreover, chemical cross-linking of structural biopolymers and proteins plays a significant role in the preparation of new materials. In order to design biomaterials that are nontoxic and biocompatible, the use of natural heterocyclic compounds isolated from plants such as genipin has been described [10]. Additionally, the biocatalyzer can be separated from the reaction by magnetism, preventing loss of particles and providing high mechanical resistance, thermal stability, and resistance against chemical and microbial degradation [11]. Furthermore, nanomaterials possessing ideal physicochemical characteristics, such as mass transfer resistance, high specific surface area, and efficient enzyme loading, can be applied as novel and interesting scaffolds for enzyme immobilization [12]. There are some reports showing efforts to unveil the properties and characteristics of new hybrid materials with an organic/inorganic composition seeking future prospects for industrial applications of immobilized enzymes requiring nonharmful or toxic agents [7, 13]. In addition, response surface methodology (RSM) technique can be used to analyze interactions of significant experimental factors and to determine the optimum response area of the tested factors, minimizing the number of experimental trials [14].

The aim of the present work was the single step synthesis of magnetic iron oxide nanoparticles coated with chitosan maximizing both the magnetic mass attracted and protein. The synthesized magnetic composite was crosslinked to two proteins using genipin as natural cross-linker, and the structural characterization was evaluated. Two hydrolytic enzymes were used as protein model in order to evaluate the protein loading and the effect of cross-linker with the composite.

\section{Materials and Methods}

2.1. Materials. Genipin ( $90 \% w / w$ purity) was purchased from Guangxi SYBiochemical Science \& Technology Co., Liuzhou, Guangxi, China. Dyadic Xylanase 2XP CONC (EC 3.2.1.8 endo-1,4- $\beta$-xylanase from Trichoderma longibrachiatum) was purchased from Dyadic International Inc, Jupiter, FL, USA. Cellulase (endo- $\beta$-glucanase from Trichoderma viride 3-10 units/mg), low molecular weight chitosan (50-190 kDa, 75-85\% deacetylated), and all chemicals were of analytical grade and purchased from Sigma-Aldrich (St. Louis, MO, USA), except those indicated. Xylanase and cellulase were used as model proteins to assess the protein loading assays, and the effect of cross-linking over enzymatic activity will be discussed in another manuscript.

\subsection{Preparation of Chitosan-Coated Magnetite Particles} ( $\mathrm{Fe}_{3} \mathrm{O}_{4} @$ Chitosan). The chitosan-coated magnetite particles were prepared by in situ coprecipitation of iron salts in a polymer template. An amount of $3.6 \times 10^{-3}$ moles of iron from a mixture in a molar ratio $2: 1\left(\mathrm{Fe}^{3+}: \mathrm{Fe}^{2+}\right)$ of ferric nitrate and ferrous sulfate added with varying amounts of chitosan $(0.5$ to $1.5 \% w / v)$ was mixed at $100 \mathrm{rpm}$ in $3 \%(v / v)$ acetic acid at $70^{\circ} \mathrm{C}$. The solid content remained constant by adjusting solution volume. The chitosan-iron solution was dispersed by an ultrasonic processor $(70 \%$ amplitude, VC505, Sonics \& Materials, Newtown, CT, USA) at different times ( 3 to $10 \mathrm{~min}$ ) to promote better distribution of compounds. Thereafter, the generated chitosaniron solution was precipitated by adding a solution of $20 \%(w / v) \mathrm{NaOH}: 96 \%(v / v)$ ethanol in $4: 1$ volume ratio. Subsequently, the alkaline mixture was homogenized using a vortex for $30 \mathrm{~s}$ and then was kept under gentle shaking $(60 \mathrm{rpm})$ for $18 \mathrm{~h}$. The precipitate was recovered by centrifugation for $5 \mathrm{~min}$ at $7000 \times \mathrm{g}$ (Eppendorf, Mod. 5804R, Hamburg, Germany) and washed with a mixture of $50 \mathrm{mM}$ phosphate buffer $\mathrm{pH} 7.0$ and $96 \%(v / v)$ ethanol in $1: 1$ volume ratio, until neutralization. The neutralized solids were oven dried at $80^{\circ} \mathrm{C}$ for $5 \mathrm{~h}$ and ground to a fine powder using a mortar and pestle. The solid yield ( $\% w / w)$ from the synthesis reaction was determined by multiplying 100 the weight ratio of final : initial solids.

2.3. Enzyme Immobilization. $300 \mathrm{mg}$ of $\mathrm{Fe}_{3} \mathrm{O}_{4} @$ Chitosan suspended in $45 \mathrm{mg} / \mathrm{mL}$ of a mixture of xylanase and cellulase in a weight ratio $1: 0.5$ was cross-linked with genipin $(0.01$ to $0.1 \% w / v)$ in $50 \mathrm{mM}$ acetate buffer $\mathrm{pH} 4.5$. The reaction mixture was vortexed (Corning, Thermo Fisher Scientific, Hampton, NH, USA) every 10 min during one hour at room temperature $\left(25 \pm 1^{\circ} \mathrm{C}\right)$. Then, the crosslinked magnetite composite $\left(\mathrm{Fe}_{3} \mathrm{O}_{4} @\right.$ Chitosan@Proteins) was separated from the reaction mixture by an external permanent neodymium magnet $(1.2 \mathrm{~T})$, washed once with ethanol $70 \% v / v$ and then two times with Milli-Q water, and dried under vacuum at $60^{\circ} \mathrm{C}$. The amount of chitosan, genipin, and sonication time were used as variables to maximize the response (Table 1), as described in a custom design of response surface methodology (Minitab 16.2.4, 2013, Minitab Inc., State College, PA, USA). The effect of variables on the response could be described as a second order polynomial.

$$
Y=\beta_{0} \sum \beta_{i} X_{i}+\sum \beta_{i i} X_{i}^{2}+\sum \beta_{i j} X_{i} X_{j}+\varepsilon
$$

where $Y$ is the predicted response used as a dependent variable, $X_{i}$ and $X_{j}$ are the levels of variables, $\beta_{0}$ is the constant term, $\beta_{i}$ is the coefficient of the linear terms, $\beta_{i i}$ is the coefficient of the quadratic terms, and $\beta_{i j}$ is the coefficient of the cross-product terms [15]. The amount of immobilized protein on the magnetite composite $\left(\mathrm{Fe}_{3} \mathrm{O}_{4} @\right.$ Chitosan@Proteins) was determined by subtracting the final from the initial concentration of protein in the immobilization medium. Protein content was measured using the Bradford [16] protein assay with bovine serum albumin as standard. The mass of magnetite composite attracted by a permanent ferric magnet $(0.39 \mathrm{~T})$ was measured by weight (defined as mass attracted). The protein loading and the mass of magnetite composite attracted were reported relative to maximum values as relative protein loading (PL, \% $w / w)$ and relative mass attracted (MA, $\% w / w)$. The mean value 
TABLE 1: Custom design of response surface methodology to synthesize magnetic particles maximizing the amount of relative protein loading and magnetically attracted mass.

\begin{tabular}{|c|c|c|c|c|c|c|}
\hline Treatment & $\begin{array}{l}\text { Chitosan } \\
(\% w / v)\end{array}$ & Sonication time (min) & $\begin{array}{l}\text { Genipin } \\
(\% w / v)\end{array}$ & $\begin{array}{l}\text { Relative protein absorbed by support } \\
\qquad(\% w / w)\end{array}$ & $\begin{array}{l}\text { Relative mass attracted } \\
\qquad(\% w / w)\end{array}$ & PLMA* (\%) \\
\hline 1 & 1.0 & 3.0 & 0.100 & $10.40 \pm 0.34$ & $94.43 \pm 0.11$ & $73.26 \pm 0.00$ \\
\hline 2 & 0.5 & 6.5 & 0.055 & $69.59 \pm 0.42$ & $98.18 \pm 0.18$ & $90.28 \pm 0.03$ \\
\hline 3 & 1.0 & 10.0 & 0.010 & $50.11 \pm 1.64$ & $96.11 \pm 0.25$ & $84.05 \pm 0.22$ \\
\hline 4 & 1.0 & 6.5 & 0.055 & $15.50 \pm 0.23$ & $96.84 \pm 0.09$ & $74.51 \pm 3.28$ \\
\hline 5 & 0.5 & 6.5 & 0.010 & $100.00 \pm 5.59$ & $99.07 \pm 0.38$ & $98.25 \pm 1.11$ \\
\hline 6 & 1.5 & 3.0 & 0.055 & $71.58 \pm 0.47$ & $98.27 \pm 0.01$ & $90.82 \pm 0.13$ \\
\hline 7 & 1.5 & 6.5 & 0.055 & $1.55 \pm 0.24$ & $95.66 \pm 2.72$ & $72.05 \pm 2.10$ \\
\hline 8 & 0.5 & 3.0 & 0.010 & $0.63 \pm 0.18$ & $100.00 \pm 0.12$ & $75.08 \pm 0.05$ \\
\hline 9 & 1.5 & 3.0 & 0.010 & $60.82 \pm 0.21$ & $96.67 \pm 0.01$ & $87.04 \pm 0.06$ \\
\hline 10 & 1.0 & 10.0 & 0.100 & $0.69 \pm 0.05$ & $96.46 \pm 0.05$ & $72.45 \pm 0.05$ \\
\hline 11 & 1 & 6.5 & 0.055 & $15.50 \pm 0.08$ & $96.24 \pm 0.22$ & $74.52 \pm 3.01$ \\
\hline
\end{tabular}

*PLMA: $[(\mathrm{PL}+\mathrm{MA}) \times 0.5] \pm$ standard deviation $(n=3)$ of relative protein loading and relative mass attracted.

PLMA $[(\mathrm{PL}+\mathrm{MA}) \times 0.5]$ of these two response variables was maximized using the optimization software. The results were evaluated by analysis of variance (ANOVA) at a significance level $p<0.05$, and the optimized empirical model was confirmed by three replicates. The regression standard error $(S)$ and determination coefficient $\left(R^{2}\right)$ were used to evaluate the significance of the model. Preliminary experiments were conducted to evaluate the effect of $1: 1,1: 2$, and $2: 1$ molar ratio of iron $\mathrm{Fe}^{3+}: \mathrm{Fe}^{2+}$, whereas xylanase:cellulase weight ratios of $1: 1,0.5: 1$, and $1: 0.5$ were also tested (data not shown).

2.4. Characterization. All structural characterizations were conducted on the optimized composite. The magnetic properties of composites were determined at room temperature $\left(27^{\circ} \mathrm{C}\right)$ with a maximum field of $\pm 50 \mathrm{kOe}$ using a MPMSXL with a SQUID detector (Quantum Design, San Diego, CA, USA). Functional groups on the surface of the composites $\mathrm{Fe}_{3} \mathrm{O}_{4} @$ Chitosan, $\mathrm{Fe}_{3} \mathrm{O}_{4} @$ Chitosan@Proteins, and free enzymes were investigated by Fourier transform infrared (FTIR) spectrometry. A spectrometer (Perkin-Elmer, Waltham, MA, USA) fitted with a universal attenuated total reflectance accessory (U-ATR, Shelton, CT, USA) was used. Samples were scanned at wave number range of 4000$550 \mathrm{~cm}^{-1}$ with a resolution of $4 \mathrm{~cm}^{-1}$. The thermogravimetric analysis (TGA) and differential scanning calorimetry (DSC) for composites and the free enzymes were performed by a simultaneous TGA-DSC/DTA analyzer NETZSCH-STA 449 F1 Jupiter (Burlington, MA, USA) and a Perkin Elmer DSC 8500 LAB SYS calorimeter. Thermal degradation was performed at a heating rate of $10^{\circ} \mathrm{C} / \mathrm{min}$ from 25 to $600^{\circ} \mathrm{C}$ under argon atmosphere. X-ray diffraction patterns (XRD) of the $\mathrm{Fe}_{3} \mathrm{O}_{4} @$ Chitosan composite before and after enzyme immobilization were recorded on a rotating anode X-ray powder diffractometer at $40 \mathrm{kV}, 30 \mathrm{~mA}$ (Rotaflex model RU200B by Rigaku, Tokyo, Japan) with a CuK $\alpha(\lambda=1.54 \AA)$ source. Samples were scanned from $3^{\circ}$ to $90^{\circ}(2 \theta)$ at a scanning rate of $3 \% \mathrm{~min}$. The unit cell parameter of crystal structure was calculated from the peak having the highest intensity using

$$
\frac{1}{d_{h k l}^{2}}=\frac{1}{a^{2}}\left(h^{2}+k^{2}+l^{2}\right),
$$

where $d$ is the interplanar distance and can be obtained from the Bragg law, $h k l$ are the Miller indices of the crystallographic planes, and $a$ is the cell parameter. Particle size distribution of $\mathrm{Fe}_{3} \mathrm{O}_{4} @$ Chitosan and $\mathrm{Fe}_{3} \mathrm{O}_{4} @$ Chitosan@Proteins dispersed in absolute ethanol was determined by dynamic light scattering (DLS) using a Zetasizer Nano ZS, Malvern Instruments (Worcestershire, UK). Morphology of composites was characterized at $120 \mathrm{kV}$ with a JEOL 1210 transmission electron microscope (TEM) (Jeol, Tokyo, Japan). The Digital Micrograph software (Gtan, Pleasanton, CA, USA) was used to determine the particle size in the TEM images. Samples were prepared by depositing one drop of $1 \mathrm{mg}$ of sonicated $(10 \mathrm{~min})$ magnetic composites in $1 \mathrm{~mL}$ ethanol and placed in $\mathrm{Cu}$ grids. The average particle diameter was determined by measuring 25 individual particles from 5 TEM micrographs. The morphology of $\mathrm{Fe}_{3} \mathrm{O}_{4} @$ Chitosan composite before and after enzyme immobilization was studied by scanning electron microscopy (SEM) in high vacuum mode (Quanta 200 FEG-ESEM, Fei Company, Hillsboro, OR, USA) coupled with energy dispersive X-ray (EDX) for measuring elemental composition. Surface chemical composition of the composites was evaluated by X-ray photoelectron spectroscopy (XPS) at room temperature with a Specs Phoibos 150 hemispherical analyzer (Specs GmbH, Berlin, Germany) using an Al-K $\alpha$ X-ray source $(1486.6 \mathrm{eV})$.

\section{Results and Discussion}

3.1. Preparation of Chitosan-Coated Magnetite Particles and Enzyme Immobilization. The proposed method of preparing superparamagnetic nanoparticles coated in situ with chitosan was based on coprecipitation of $\mathrm{Fe}^{2+}: \mathrm{Fe}^{3+}$ salt solution under 
alkaline conditions combined with a sonication treatment maximizing protein loading and mass attraction using the RSM. A limited number of studies have employed RSM approaches to synthesize magnetic nanoparticles coated with chitosan aimed at maximizing the protein loading and mass attracted by magnetism. The yield of solids of the synthesis reaction of magnetic composites after cross-linking was $57.4 \pm 5.1 \% w / w$. The estimated regression coefficients for PLMA were statistically significant except quadratic terms for sonication and cross-linker $(p>0.05)$ (Table 1).

The regression standard error $(S)=1.5 \%$ indicates a good fit of the regression model. $S$ represents the standard distance to which data values are located relative to the regression line or the standard deviation of the residuals. The predicted sum of squares $($ PRESS $)=58.2$ indicates the predictive ability of the model and is used to calculate $R^{2}$ predicted. In general, the smaller the PRESS value, the better the model's predictive ability. $R^{2}$ value was $98.5 \%$ indicating the percentage of variation of the response variable explained by its relation to one or more predictor variables. $R^{2}$ (predicted) $=96.7 \%$ suggests a large predictive capacity of the model. $R^{2}$ (adjusted) $=97.4 \%$ is the percentage of response variable variation explained by its relationship with one or more predictor variables, adjusted for the number of predictors in the model. In general, the closer the $R^{2}$ to $100 \%$, the better the model adjustment to the data. From the analysis of variance (ANOVA, Table 2), it suggests curvature on the response surface (Figure 1). The expected model could be represented by

$$
\begin{aligned}
\text { PLMA }= & 56.23-9.60 X_{1}+11.38 X_{2}-177.50 X_{3}+26.61 X_{1}^{2} \\
& +0.11 X_{2}^{2}+104.0 X_{3}^{2}-11.23 X_{1} * X_{2}+203.10 X_{1} \\
& * X_{3}-16.60 X_{2} * X_{3},
\end{aligned}
$$

where $X_{1}=$ chitosan; $X_{2}=$ sonication; and $X_{3}=$ cross-linker.

Confirmatory experiments gave a PLMA value of 95.1 $\pm 7.6 \%(w / w)$ using the predicted global solution of response optimization with chitosan $=0.5 \% \mathrm{w} / \mathrm{w}$, sonication $=10 \mathrm{~min}$, and cross-linker $=0.01 \% v / v$, in agreement with the predicted value. The curve in Figure 1 showed a positive effect on PLMA value when longer sonication time and lower concentrations of both chitosan and genipin were used.

It was expected that ultrasonic treatment could promote low $\mathrm{Fe}_{3} \mathrm{O}_{4}$ crystal sizes and homogeneous distribution inside the polymeric matrix of chitosan, to obtain more composite mass able of attraction by an external magnet. In addition, application of higher ultrasound energy $(10 \mathrm{~min})$ to samples containing low amounts of chitosan $(0.5 \% \mathrm{w} / \mathrm{v})$ could produce smaller particles providing multiple protein anchor points through the cross-linking agent. Besides, the extent of cross-linking between protein and genipin can be high (about $80-86 \%$ ) even at low genipin addition [17]. A limited number of studies have employed RSM approaches to optimize the generation of magnetic nanoparticles for enzyme immobilization. RSM keeps the number of experiments to a minimum for a relatively large number of significant factors as compared to those involving the simple, time consuming "one factor at a time" design [18].
The procedure shown in this work is fast and simple and requires no harmful chemicals as previously described [2, 19], despite the inclusion of a sonication process. Nanobiocatalysts combining enzymes and nanocarriers are drawing increased attention because of their high catalytic performance, enhanced stability, improved enzyme-substrate affinity, and reusability [20-22]. Genipin is a heterocycle of natural origin used as a nontoxic chemical for cross-linking of proteins and polysaccharides [10]. Thus, genipin is widely used to replace glutaraldehyde and formaldehyde as a biological cross-linking agent for proteins due to about 10,000 times less toxic [17]. Therefore, the composite synthesized can be used in such applications where safety issues are important as food or pharmaceuticals. Therefore, the composite synthesized can be used in applications where safety issues are important such as food or pharmaceutical industry. A perspective for food or pharmaceutical applications is the hydrolysis of residues (xylo- and cello-oligossaccharides).

3.2. Characterization. As shown in Figure 2, the magnetic hysteresis loops recorded at $27^{\circ} \mathrm{C}$ revealed that whole sample of $\mathrm{Fe}_{3} \mathrm{O}_{4} @$ Chitosan, $\mathrm{Fe}_{3} \mathrm{O}_{4} @$ Chitosan@Proteins, and $\mathrm{Fe}_{3} \mathrm{O}_{4}$ particles had a magnetization saturation value of $57 \mathrm{emu} / \mathrm{g}$, $55 \mathrm{emu} / \mathrm{g}$, and $59 \mathrm{emu} / \mathrm{g}$, respectively, using $50 \mathrm{kOe}$ of magnetic field.

Practically zero remanence $(0.3197 \mathrm{emu} / \mathrm{g}, 1.038 \mathrm{emu} / \mathrm{g}$, and $1.328 \mathrm{emu} / \mathrm{g}$ for $\mathrm{Fe}_{3} \mathrm{O}_{4}, \mathrm{Fe}_{3} \mathrm{O}_{4} @$ Chitosan, and $\mathrm{Fe}_{3} \mathrm{O}_{4} @$ Chitosan@Proteins, resp.) and scarce coercivity (3.724 Oe, 13.772 Oe, and $17.360 \mathrm{Oe}$ for $\mathrm{Fe}_{3} \mathrm{O}_{4}, \mathrm{Fe}_{3} \mathrm{O}_{4} @$ Chitosan, and $\mathrm{Fe}_{3} \mathrm{O}_{4} @$ Chitosan@Proteins, resp.) were detected in the samples. These values indicated that magnetic composites maintained the superparamagnetic behavior of the $\mathrm{Fe}_{3} \mathrm{O}_{4}$ particles, suggesting barely magnetic behavior in the absence of an external magnetic field, but mean magnetic moment development in an external magnetic field, but they develop a mean magnetic moment in an external magnetic field $[3,19]$. The magnetization of coated magnetite was weaker than uncoated $\mathrm{Fe}_{3} \mathrm{O}_{4}$ as expected, because of the presence of chitosan and enzymes. The saturation magnetization values are consistent with those reported in the literature for magnetite nanoparticles $[2,9,21]$. Most biological materials including enzymes and chitosan exhibit diamagnetic or nonmagnetic properties. Thus, selective magnetic separation can be achieved using magnetically responsive immobilized enzymes from biological mixtures $[12,13]$.

To further evaluate the enzyme cross-linking on the surface of $\mathrm{Fe}_{3} \mathrm{O}_{4} @$ Chitosan, their FTIR spectra were also obtained. The FTIR spectra of chitosan and $\mathrm{Fe}_{3} \mathrm{O}_{4}$ are well documented [23, 24]. Figure 3 shows the FTIR spectra obtained for $\mathrm{Fe}_{3} \mathrm{O}_{4} @$ Chitosan, $\mathrm{Fe}_{3} \mathrm{O}_{4} @$ Chitosan@Proteins, and free enzymes.

The spectrum of the enzymes showed signals around $2940 \mathrm{~cm}^{-1}$, corresponding to $\mathrm{C}-\mathrm{H}$ bonds in $\mathrm{CH}_{2}$ and $\mathrm{CH}_{3}$ groups, as well as a signal at $3300 \mathrm{~cm}^{-1}$ assigned to the $\mathrm{OH}$ bonds. The bands between $1350 \mathrm{~cm}^{-1}$ and $1650 \mathrm{~cm}^{-1}$ are related to amine groups $\left(\mathrm{NH}_{2}\right)$ present in both chitosan and enzymes. Signals between $1900 \mathrm{~cm}^{-1}$ and $1200 \mathrm{~cm}^{-1}$ which correspond to $\mathrm{C}-\mathrm{O}$ bonds in the enzymes were diminished after cross-linking with $\mathrm{Fe}_{3} \mathrm{O}_{4} @$ Chitosan. Some of the 
TABLE 2: Analysis of variance (ANOVA) for the custom design of response surface methodology to synthesize magnetic particles maximizing the amount of relative protein loading and magnetically attracted mass.

\begin{tabular}{|c|c|c|c|c|c|}
\hline Source & $\mathrm{DF}$ & Sum of squares adjusted & Mean square adjusted & $F$ value & $p$ value Prob $>F$ \\
\hline Model & 9 & 1715.75 & 190.639 & 89.45 & 0.001 \\
\hline Lineal & 3 & 451.64 & 150.546 & 70.64 & 0.001 \\
\hline Chitosan & 1 & 332.10 & 332.096 & 155.83 & 0.001 \\
\hline Sonication & 1 & 34.66 & 34.659 & 16.26 & 0.002 \\
\hline Cross-linker & 1 & 72.28 & 72.285 & 33.92 & 0.001 \\
\hline Square & 3 & 89.31 & 29.769 & 13.97 & 0.001 \\
\hline Chitosan $\times$ chitosan & 1 & 88.53 & 88.529 & 41.54 & 0.001 \\
\hline Sonication $\times$ sonication & 1 & 3.45 & 3.452 & 1.62 & 0.227 \\
\hline Cross-linker $\times$ cross-linker & 1 & 0.09 & 0.088 & 0.04 & 0.842 \\
\hline Interaction & 3 & 984.29 & 328.097 & 153.95 & 0.001 \\
\hline Chitosan $\times$ sonication & 1 & 722.13 & 722.131 & 338.84 & 0.001 \\
\hline Chitosan $\times$ cross-linker & 1 & 39.02 & 39.025 & 18.31 & 0.001 \\
\hline Sonication $\times$ cross-linker & 1 & 48.61 & 48.608 & 22.81 & 0.001 \\
\hline Error & 12 & 25.57 & 2.131 & & \\
\hline Total & 21 & 1741.33 & & & \\
\hline
\end{tabular}

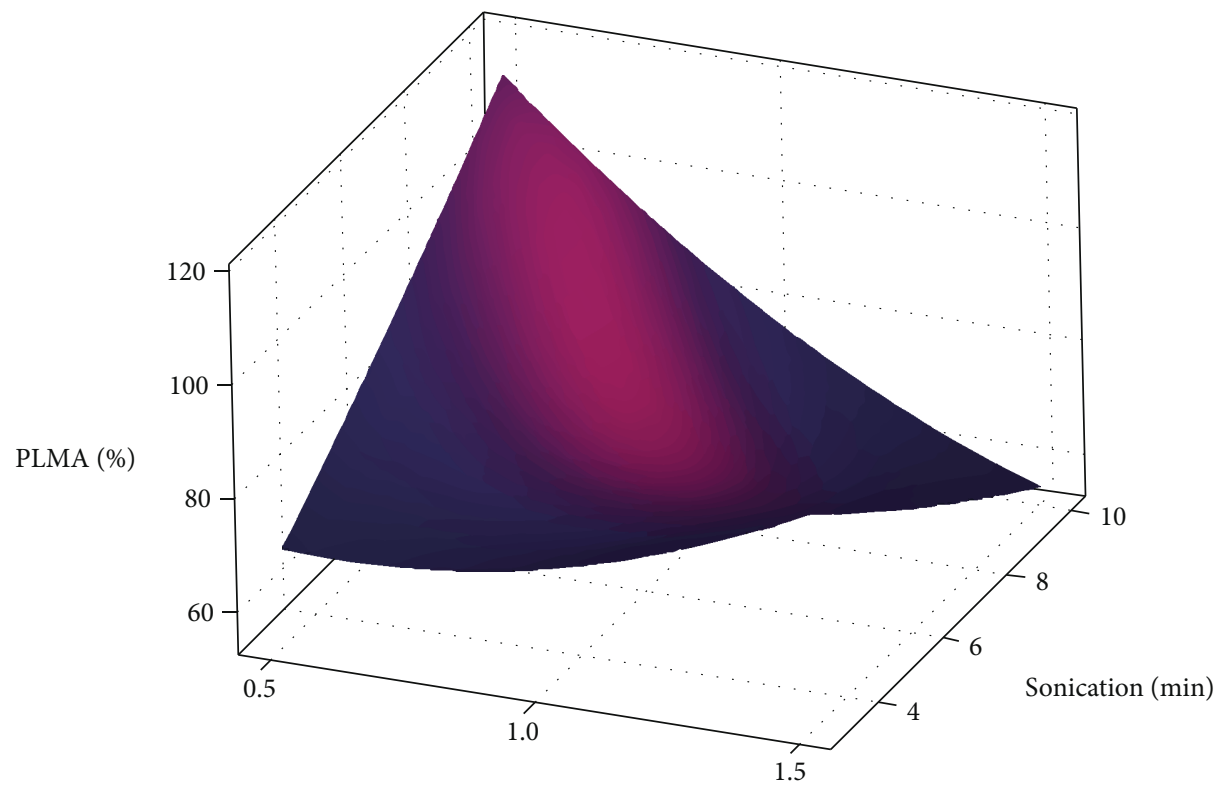

Chitosan (\%)

FIGURE 1: Response surface methodology (RSM) curve of maximizing desirability PLMA value as a function of the parameters of the experimental design (i.e., the amount of chitosan, genipin, and sonication time).

signals that were identified below $1000 \mathrm{~cm}^{-1}$ can be assigned to $\mathrm{C}-\mathrm{C}$ bonds. Typical bands below $700 \mathrm{~cm}^{-1}$ identified as $\mathrm{Fe}-\mathrm{O}$ bonds characteristic of magnetite were observed in all spectra around $570 \mathrm{~cm}^{-1}$. In addition, the change in intensity as well as the displacement of the $\mathrm{NH}_{2}, \mathrm{C}-\mathrm{O}$, and $\mathrm{Fe}$ bands after cross-linking suggests the formation of covalent bonds between enzymes and $\mathrm{Fe}_{3} \mathrm{O}_{4} @$ Chitosan $[21,25]$. However, inconclusive reports about the molar ratio of chitosan/genipin or the molar ratio between reacted amino groups and free amino groups of chitosan can be found in the literature, despite the extremely good analytical instrumentation available [26].

The thermal properties of particles were evaluated by TGA and DSC. TGA of all samples was performed in the range $25-600^{\circ} \mathrm{C}$ : the enzyme stability can be observed in the $25-150^{\circ} \mathrm{C}$ interval. The weight loss curves of coated and uncoated MNPs, free enzymes, and immobilized enzyme MNPs are shown in Figure 4.

The thermal degradation of all the samples displays three main stages in the temperature range of $25-600^{\circ} \mathrm{C}$. In a first 


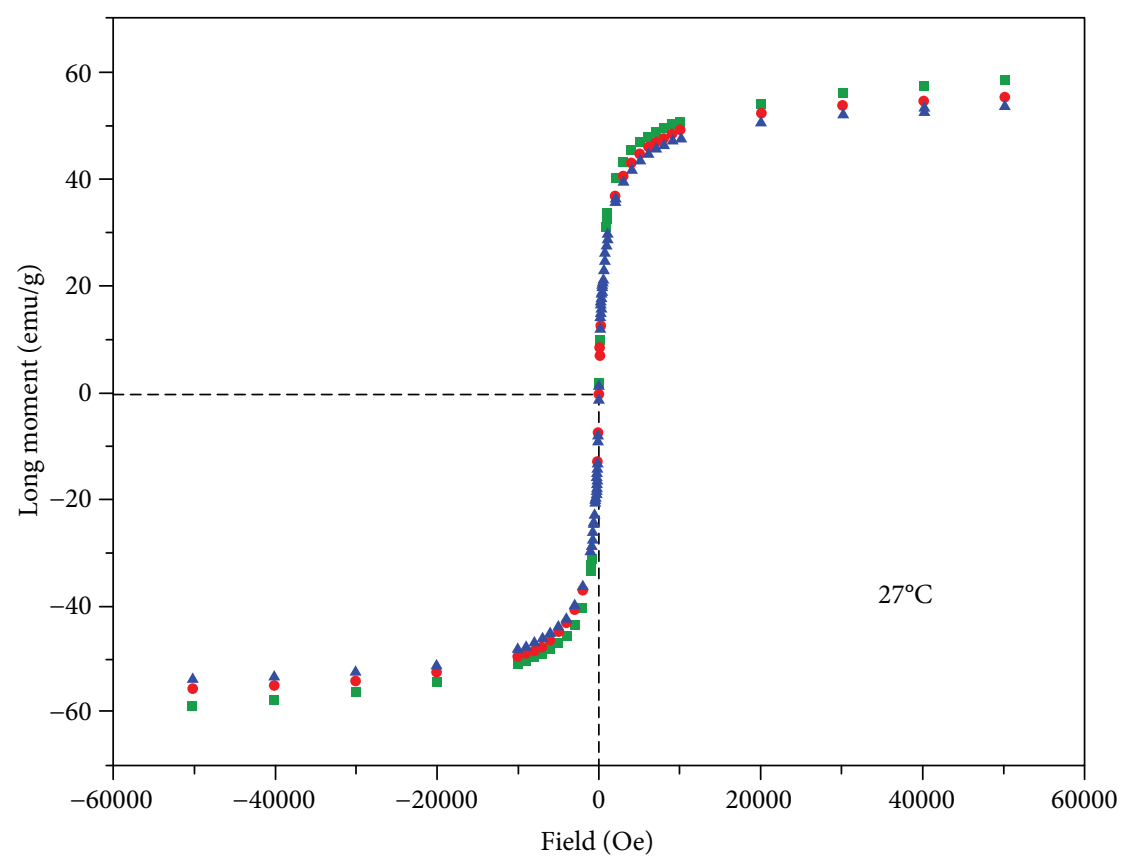

Figure 2: Magnetization curves of whole sample of $\mathrm{Fe}_{3} \mathrm{O}_{4}, \mathrm{Fe}_{3} \mathrm{O}_{4} @$ Chitosan, and $\mathrm{Fe}_{3} \mathrm{O}_{4} @$ Chitosan@Proteins. Fe $\mathrm{O}_{4}$ (green square), $\mathrm{Fe}_{3} \mathrm{O}_{4} @$ Chitosan (red circle), and $\mathrm{Fe}_{3} \mathrm{O}_{4} @$ Chitosan@Proteins (blue triangle).

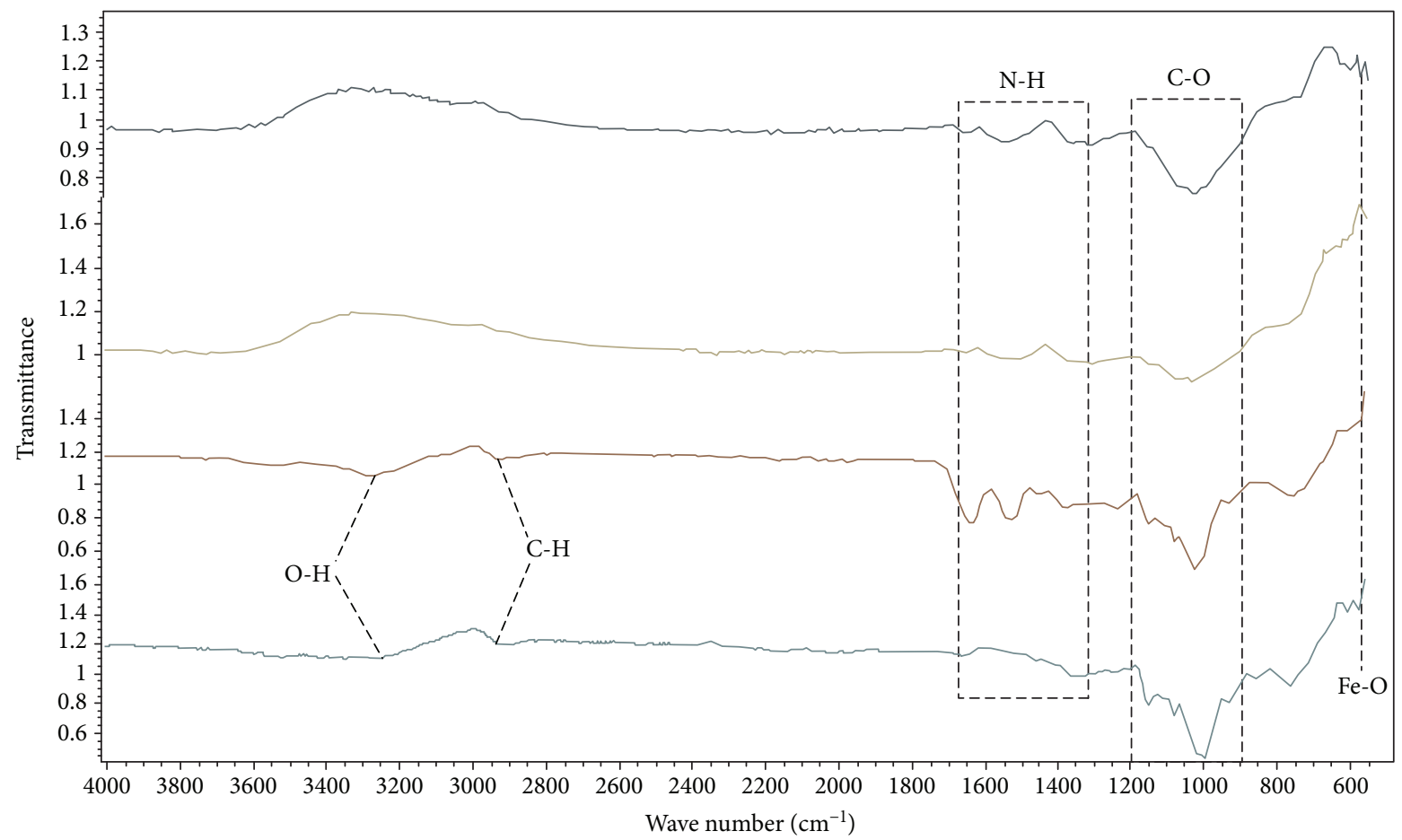

Figure 3: FTIR spectra of free enzymes, $\mathrm{Fe}_{3} \mathrm{O}_{4} @$ Chitosan, and $\mathrm{Fe}_{3} \mathrm{O}_{4} @$ Chitosan@Proteins. $\mathrm{Fe}_{3} \mathrm{O}_{4} @ C h i t o s a n$ (dark blue), $\mathrm{Fe}_{3} \mathrm{O}_{4} @$ Chitosan@Proteins (yellow), xylanase (red), and cellulase (light blue).

stage, the thermogram profiles of $\mathrm{Fe}_{3} \mathrm{O}_{4} @$ Chitosan and $\mathrm{Fe}_{3} \mathrm{O}_{4} @$ Chitosan@Proteins show similar weight loss behavior, of approximately $1.4 \%$ at temperatures ranging from 65 to $120^{\circ} \mathrm{C}$. Also, a weight loss of $2.3 \%, 2.5 \%$, and $2.3 \%$ was observed for xylanase, cellulase, and $\mathrm{Fe}_{3} \mathrm{O}_{4}$, respectively, under the same temperature range. This loss of weight in the first stage is mainly due to the loss of low molecular mass compounds, mainly adsorbed and partly bound water. Additionally, $\mathrm{Fe}_{3} \mathrm{O}_{4} @$ Chitosan and $\mathrm{Fe}_{3} \mathrm{O}_{4} @$ Chitosan@Proteins show a first change in heat flow associated with thermal 


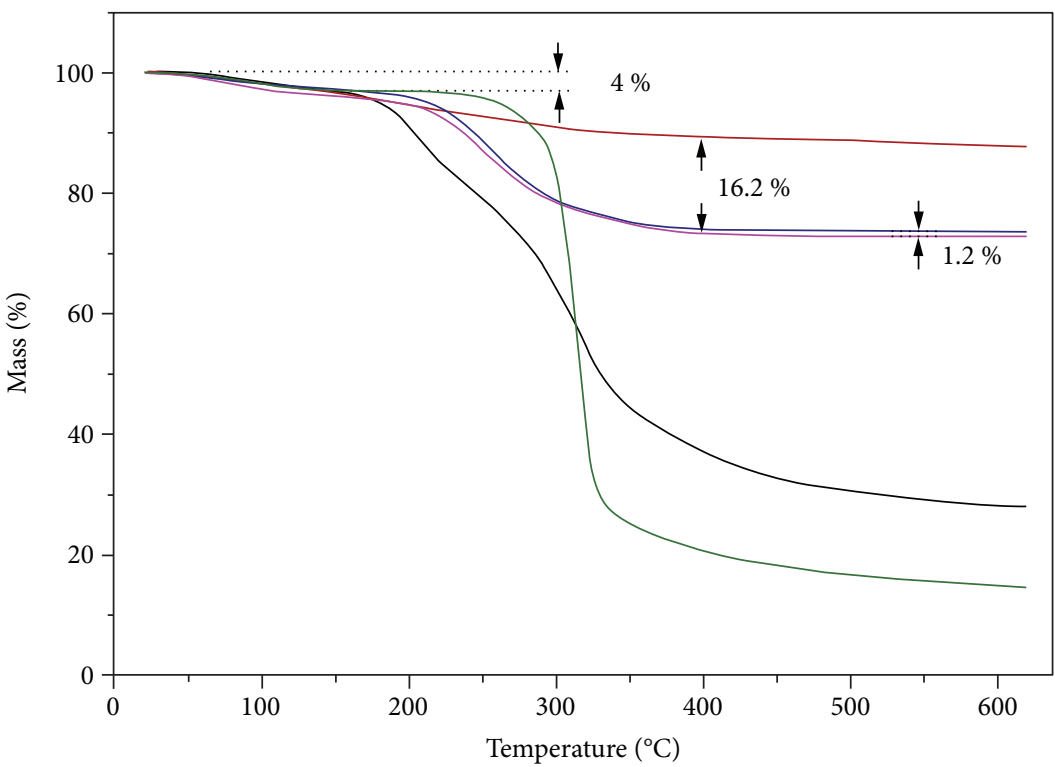

Figure 4: Thermogravimetric profiles of free enzymes, $\mathrm{Fe}_{3} \mathrm{O}_{4}, \mathrm{Fe}_{3} \mathrm{O}_{4} @$ Chitosan, and $\mathrm{Fe}_{3} \mathrm{O}_{4} @$ Chitosan@Proteins. Xylanase (black), cellulase (green), $\mathrm{Fe}_{3} \mathrm{O}_{4}$ (red), $\mathrm{Fe}_{3} \mathrm{O}_{4} @$ Chitosan (blue), and $\mathrm{Fe}_{3} \mathrm{O}_{4} @$ Chitosan@Proteins (pink).

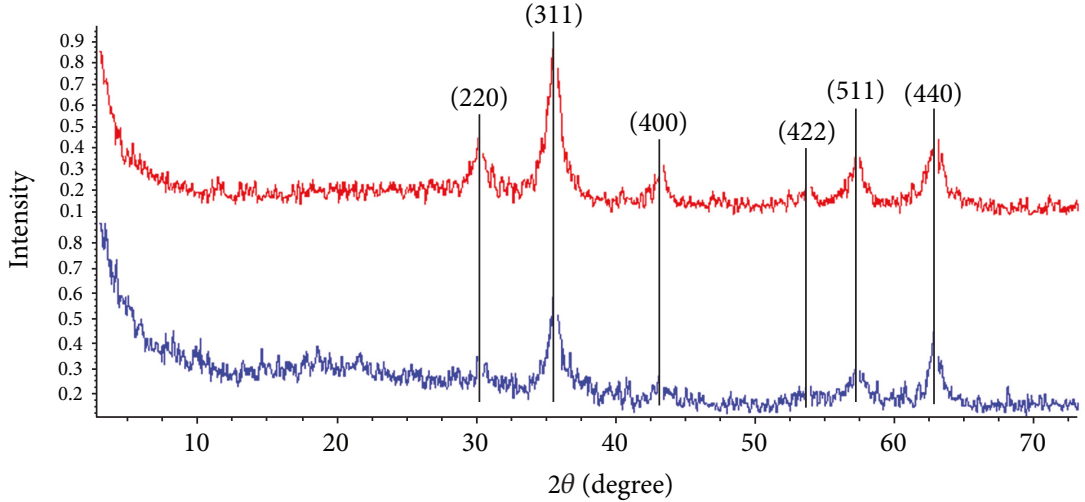

FIGURE 5: XRD patterns of $\mathrm{Fe}_{3} \mathrm{O}_{4} @$ Chitosan and $\mathrm{Fe}_{3} \mathrm{O}_{4} @$ Chitosan@Proteins (signals from diffraction planes are indicated by solid lines). $\mathrm{Fe}_{3} \mathrm{O}_{4} @$ Chitosan (red) and $\mathrm{Fe}_{3} \mathrm{O}_{4} @$ Chitosan@Proteins (blue).

transitions at $39^{\circ} \mathrm{C}$ and $41^{\circ} \mathrm{C}$, slightly higher than xylanase $38^{\circ} \mathrm{C}$, cellulase $30^{\circ} \mathrm{C}$, and $\mathrm{Fe}_{3} \mathrm{O}_{4} 35^{\circ} \mathrm{C}$. Furthermore, all samples except $\mathrm{Fe}_{3} \mathrm{O}_{4} @$ Chitosan@Proteins and $\mathrm{Fe}_{3} \mathrm{O}_{4}$ show an exothermic signal associated with structural changes or bond breaking, whereas the endothermic behavior is associated with the absorption of energy probably due to protein denaturation. A further temperature increase to $120-300^{\circ} \mathrm{C}$ in a second stage results in a total weight loss of $12.9 \%, 40.5 \%$, $39.6 \%, 86.7 \%$, and $96.2 \%$ for $\mathrm{Fe}_{3} \mathrm{O}_{4}, \mathrm{Fe}_{3} \mathrm{O}_{4} @$ Chitosan, $\mathrm{Fe}_{3} \mathrm{O}_{4} @$ Chitosan@Proteins, cellulase, and xylanase, respectively. This process corresponds to the degradation of the chitosan, genipin, proteins, and structurally bound water. The third stage with the highest degradation rate at about $300-600^{\circ} \mathrm{C}$ is the complete degradation of organic compounds. The difference in mass between $\mathrm{Fe}_{3} \mathrm{O}_{4} @$ Chitosan and $\mathrm{Fe}_{3} \mathrm{O}_{4} @$ Chitosan@Proteins can be correlated with the mass of protein cross-linked to the magnetic composite, as well as the mass of chitosan present in the magnetic compound can also be correlated with the loss of mass between and the mass difference between $\mathrm{Fe}_{3} \mathrm{O}_{4}$ and $\mathrm{Fe}_{3} \mathrm{O}_{4} @$ Chitosan. Thus, TGA profiles showed that on average, $162 \mathrm{mg}$ of chitosan was coating one gram of composite, and $12 \mathrm{mg}$ of protein was cross-linked to each gram of magnetic support. The mass balance of protein calculated with TGA data was confirmed on the basis of the amount of proteins added and amount of proteins immobilized using Bradford assay (data not shown). TGA is frequently used to confirm the immobilization of enzymes on MNPs by determining the percentage loss of weight of the naked MNPs and enzyme immobilized MNPs [15].

The XRD patterns of magnetic composites are shown in Figure 5.

Well-resolved peaks were observed, indicating that the magnetic particle structure remains essentially unchanged during the coating with chitosan and enzyme cross-linking reaction. The six signals depicted in XRD spectrum of the 
Size distribution by intensity

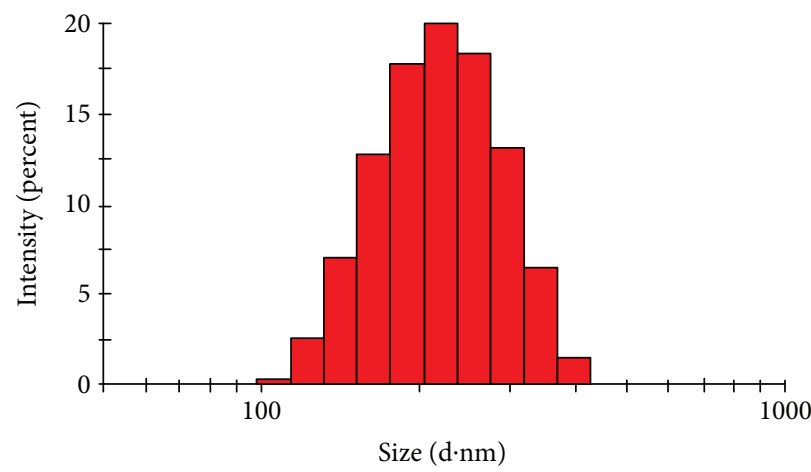

(a)
Size distribution by intensity

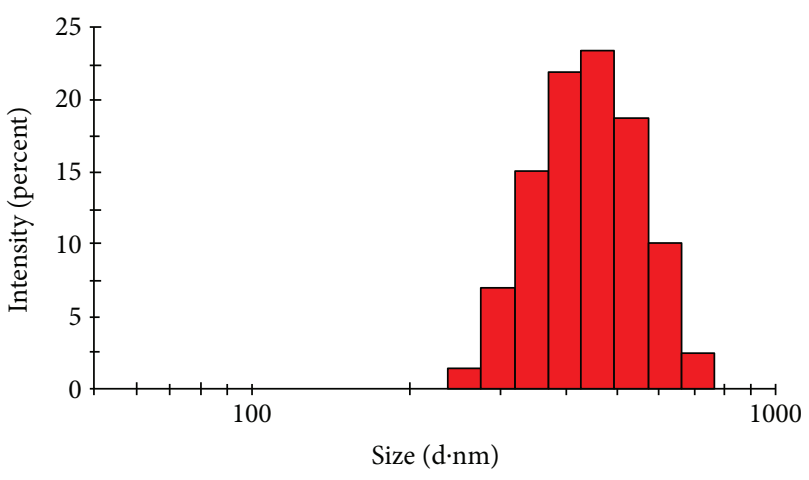

(b)

Figure 6: DLS histograms of size distribution particles of (a) $\mathrm{Fe}_{3} \mathrm{O}_{4} @$ Chitosan and (b) $\mathrm{Fe}_{3} \mathrm{O}_{4} @$ Chitosan@Proteins.

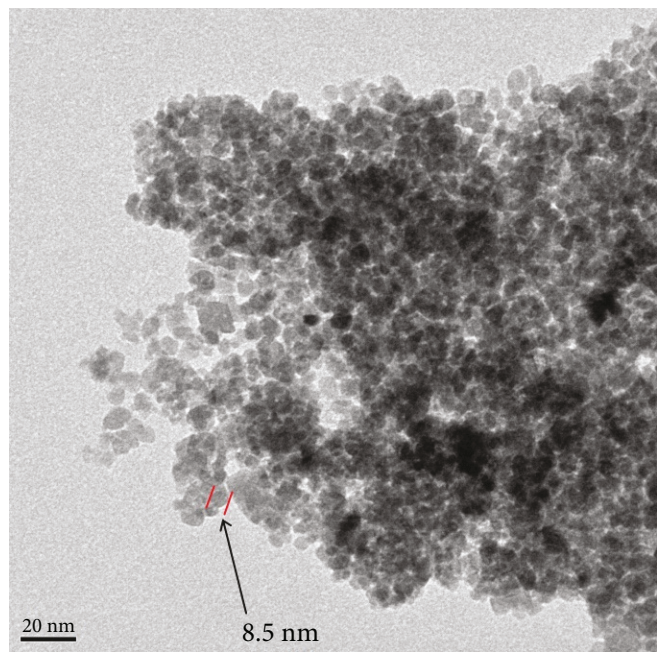

(a)

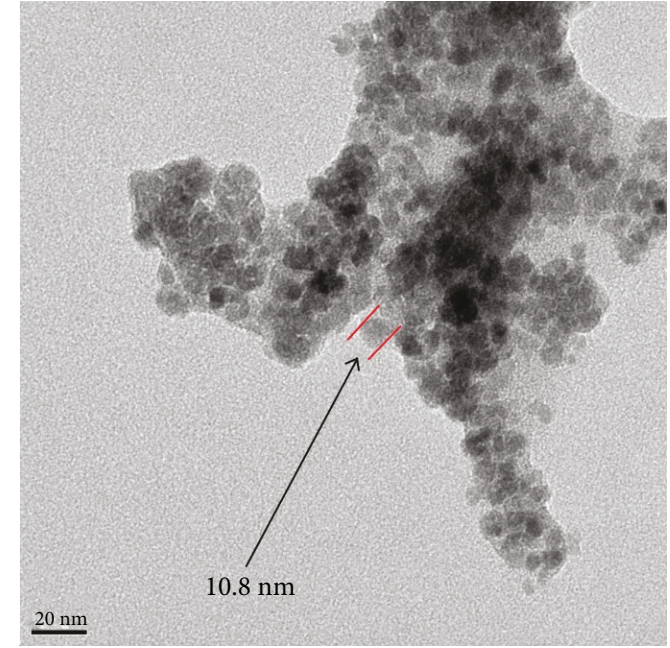

(b)

Figure 7: TEM images of (a) $\mathrm{Fe}_{3} \mathrm{O}_{4} @$ Chitosan and (b) $\mathrm{Fe}_{3} \mathrm{O}_{4} @$ Chitosan@Proteins.

composites at $2 \theta=30.1^{\circ}, 35.3^{\circ}, 43.1^{\circ}, 53.5^{\circ}, 56.9^{\circ}$, and $62.7^{\circ}$ correspond to the planes $\left(\begin{array}{lll}2 & 2 & 0\end{array}\right),\left(\begin{array}{lll}3 & 1 & 1\end{array}\right),\left(\begin{array}{lll}4 & 0 & 0\end{array}\right),\left(\begin{array}{lll}4 & 2 & 2\end{array}\right)$, $\left(\begin{array}{lll}5 & 1 & 1\end{array}\right)$, and (4 40 ), which are characteristic of $\mathrm{Fe}_{3} \mathrm{O}_{4}$ [4]. However, it is expected to find residual maghemite $(\gamma$ $\mathrm{Fe}_{2} \mathrm{O}_{3}$ ) in the samples due to low-temperature oxidation of spinels containing iron (II) such as magnetite. The patterns could be perfectly synchronized with the cubic structure of the inverse spinel of pure $\mathrm{Fe}_{3} \mathrm{O}_{4}$, with a lattice constant $a$ $=0.83 \mathrm{~nm}$ and a unit cell comprising $24 \mathrm{Fe}$ and $32 \mathrm{O}$ atoms, respectively. A faint reflection peak was observed at $18^{\circ}$ assigned to maghemite, but the intensity was so low that it was neglected; therefore, it is concluded that high purity and good crystallinity were obtained with the synthesis method proposed. The magnetic properties of $\mathrm{Fe}_{3} \mathrm{O}_{4}$ are directly proportional to the type and distribution of the cations at octahedral and tetrahedral sites of the spinel structure [2].

DLS was used to obtain the particle size distribution of $\mathrm{Fe}_{3} \mathrm{O}_{4} @$ Chitosan and $\mathrm{Fe}_{3} \mathrm{O}_{4} @$ Chitosan@Proteins. Figure 6(a) indicates that $\mathrm{Fe}_{3} \mathrm{O}_{4} @$ Chitosan particles have a size distribution of $120-300 \mathrm{~nm}$ with an average of approximately $230 \mathrm{~nm}$. Figure 6(b) indicates that the $\mathrm{Fe}_{3} \mathrm{O}_{4} @$ Chitosan@Proteins have a size distribution of $150-670 \mathrm{~nm}$ with an average of $430 \mathrm{~nm}$.

Furthermore, TEM micrographs show clusters of individual spherical particles (see Figure 7).

The average particle size of $\mathrm{Fe}_{3} \mathrm{O}_{4} @$ Chitosan slightly increased from $8.5 \pm 0.14 \mathrm{~nm}$ (Figure $7(\mathrm{a})$ ) to $10.8 \pm 0.40 \mathrm{~nm}$ (Figure 7(b)) in $\mathrm{Fe}_{3} \mathrm{O}_{4} @$ Chitosan@Proteins after crosslinking reaction with genipin. In addition, from the calculated lattice constant, we can assume that each nanoparticle comprises ten unit cells. Figure 7 (a) shows regular and defined shapes, opposite to Figure 7 (b) where a layer covering the surface of MNPs upon mobilization of the enzymes can be seen.

Besides, the $\mathrm{Fe}_{3} \mathrm{O}_{4} @$ Chitosan samples show regular and defined shapes contrasting with the $\mathrm{Fe}_{3} \mathrm{O}_{4} @$ Chitosan@Proteins samples, where agglomerates can be seen. TEM suggests 


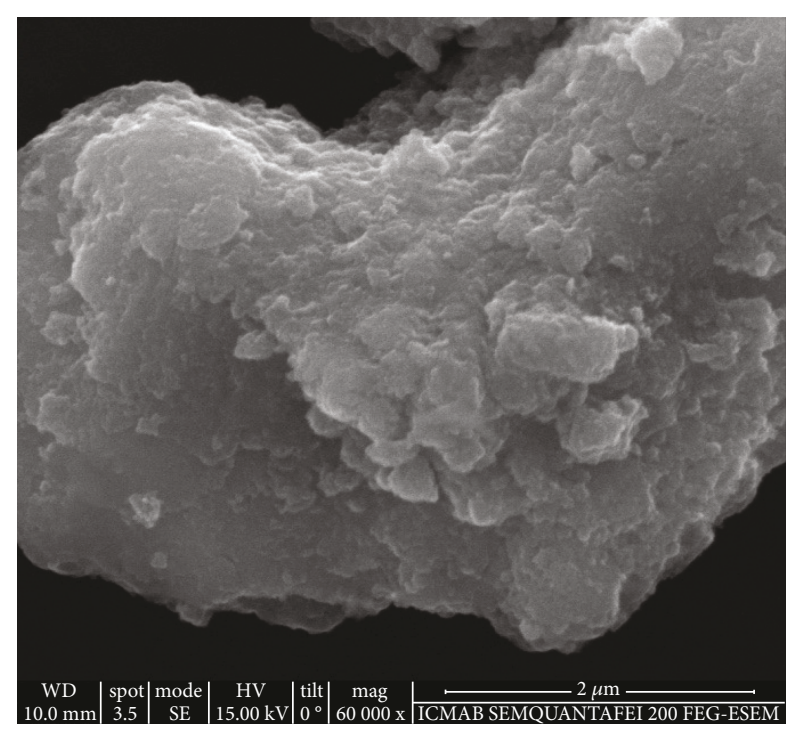

(a)

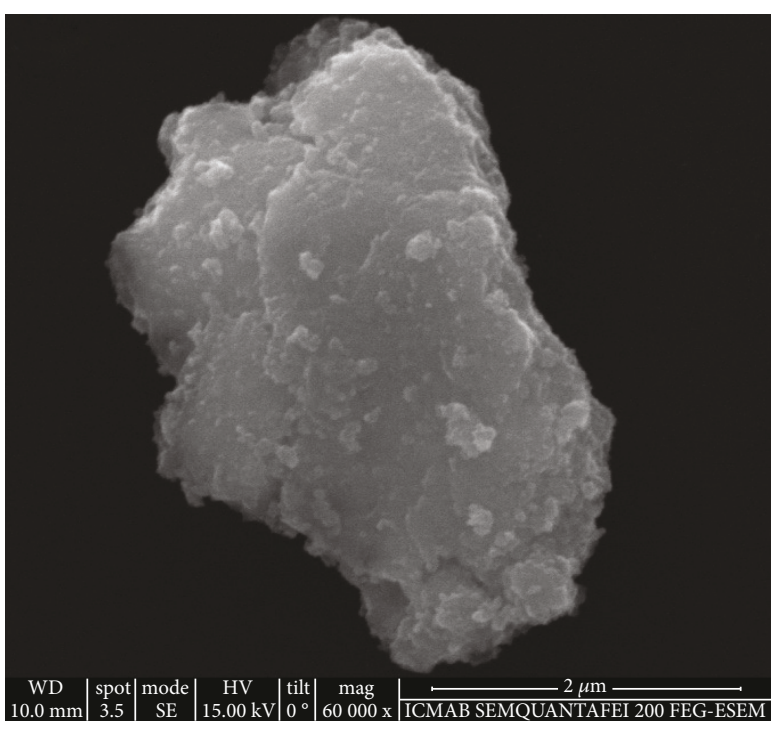

(b)

Figure 8: SEM images of (a) $\mathrm{Fe}_{3} \mathrm{O}_{4} @$ Chitosan and (b) $\mathrm{Fe}_{3} \mathrm{O}_{4} @$ Chitosan@Proteins.

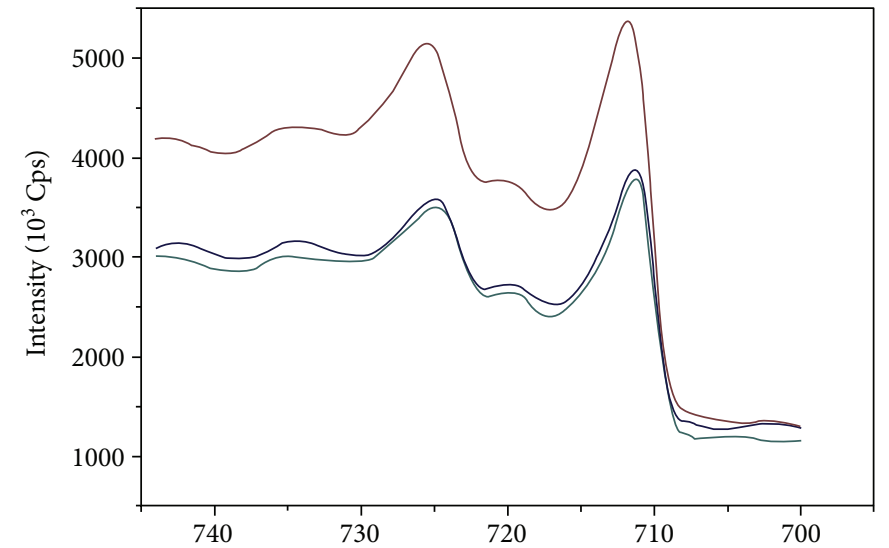

(a)

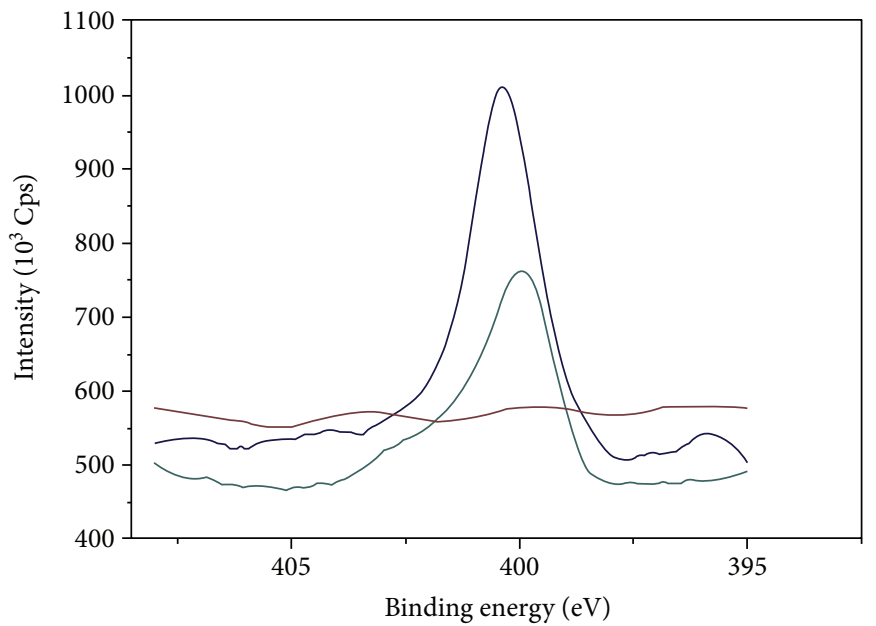

(c)

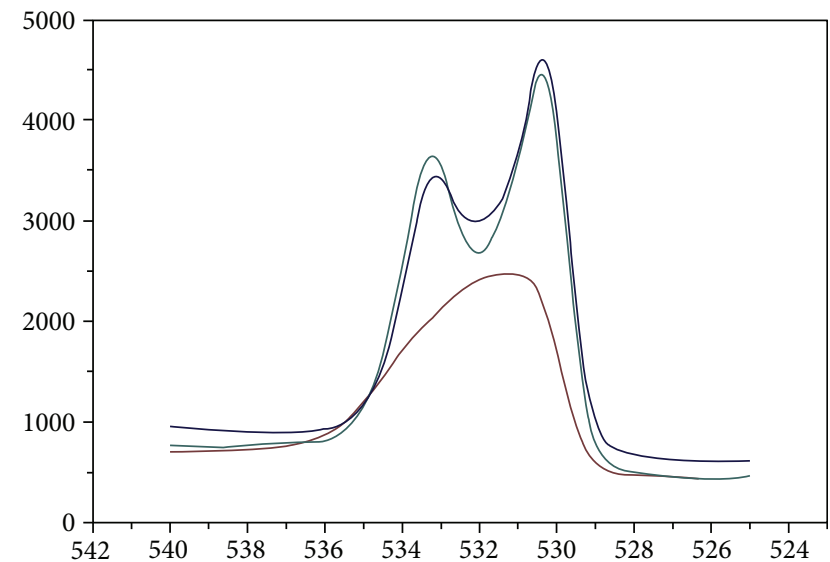

(b)

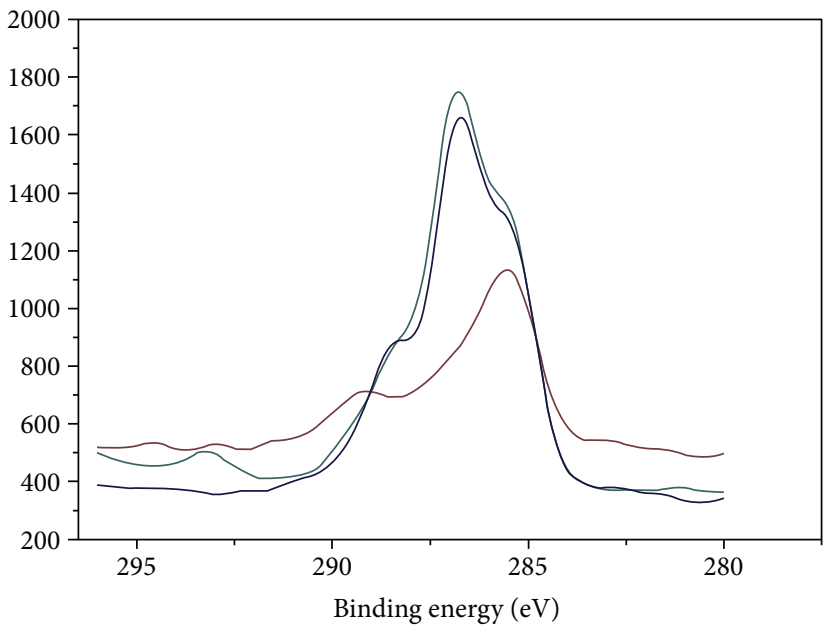

(d)

Figure 9: Fully scanned XPS spectra of $\mathrm{Fe}_{3} \mathrm{O}_{4}, \mathrm{Fe}_{3} \mathrm{O}_{4} @$ Chitosan, and $\mathrm{Fe}_{3} \mathrm{O}_{4} @$ Chitosan@Proteins; XPS spectra of Fe2p (a), O1s (b), N1s (c), and $\mathrm{C} 1 \mathrm{~s}$ (d). $\mathrm{Fe}_{3} \mathrm{O}_{4}$ (red), $\mathrm{Fe}_{3} \mathrm{O}_{4} @$ Chitosan (green), and $\mathrm{Fe}_{3} \mathrm{O}_{4} @$ Chitosan@Proteins (blue). 
that after enzyme immobilization within the composite, the MNPs have larger sizes that evidence enzymes and chitosan cross-linking, as has been previously documented [21, 2729]. Moreover, it has been documented that $\mathrm{Fe}_{3} \mathrm{O}_{4}$ is superparamagnetic when its size is around 10 to $20 \mathrm{~nm}[3,19]$, which agrees with the superparamagnetic properties of our composites (see Figure 1). Heterogeneous morphology of clusters was also confirmed by SEM (Figure 8).

The interaction between the $\mathrm{Fe}_{3} \mathrm{O}_{4} @$ Chitosan and enzymes was confirmed by EDX analysis. The chemical composition $(\% w / w)$ in $\mathrm{Fe}, \mathrm{O}, \mathrm{C}$, and $\mathrm{N}$ of $\mathrm{Fe}_{3} \mathrm{O}_{4} @$ Chitosan was $65.88 \pm 1.42,21.91 \pm 2.03,9.88 \pm 0.97$, and $1.06 \pm 0.96$, respectively. A decrease of $22.4 \%$ in Fe concentration of $\mathrm{Fe}_{3} \mathrm{O}_{4} @$ Chitosan@Proteins was noticed. However, increased concentrations of $15.15 \%, 99.60 \%$, and $84.91 \%$ with elements associated to proteins such as oxygen (O), carbon (C), and nitrogen $(\mathrm{N})$ were detected, respectively. A narrow characterization of the elemental composition of magnetic composites was performed with XPS analysis using $\mathrm{Fe}_{3} \mathrm{O}_{4}$ as reference. Figure 9 shows the high-resolution XPS spectrum of the Fe, $\mathrm{O}, \mathrm{N}$, and $\mathrm{C}$ components of the samples.

The presence of the magnetite in all samples (Figure 9(a)) is confirmed according to the characteristic peaks of Fe2p at 711 and $725 \mathrm{eV}$ and for the $\mathrm{Fe} 3 \mathrm{p}$ line around $60 \mathrm{eV}$, in agreement with [30]. In Figure 9(b), changes in signal intensities for O1s spectra were observed in all samples. Characteristic peaks (between 530 and $534 \mathrm{eV}$ ) were identified as $531.5 \mathrm{eV}$ to $\mathrm{C}-\mathrm{O}$ and $533 \mathrm{eV}$ to $\mathrm{C}=\mathrm{O}$. The presence of the $\mathrm{N} 1 \mathrm{~s}$ was identified at $401 \mathrm{eV}$ (Figure 9(c)). A 2-fold change in N1s spectra is present in $\mathrm{Fe}_{3} \mathrm{O}_{4} @$ Chitosan@Proteins when compared with $\mathrm{Fe}_{3} \mathrm{O}_{4} @$ Chitosan. Slight signal variation corresponding to C1s (Figure 9(d)) was identified in a range of approximately $284-290 \mathrm{eV}$; in this range, the signals corresponded to $\mathrm{O}-\mathrm{C}=\mathrm{O}(\sim 288 \mathrm{eV}), \mathrm{C}-\mathrm{O}-\mathrm{C}(\sim 287 \mathrm{eV})$, and C-C ( 286 eV).

As this type of nanoparticles used as support for enzyme immobilization might result in significant losses of enzymatic activities, the exhibited structural properties for the $\mathrm{Fe}_{3} \mathrm{O}_{4} @$ Chitosan@Proteins will further be correlated with a complete study on the enzymatic activity of biocatalysts.

\section{Conclusions}

The synthesis of magnetic nanoparticles coated with chitosan was performed in a single step and has potential application in enzyme immobilization by a natural and low toxic crosslinker agent. The preparation method plays a key role in determining the particle size and shape, size distribution, surface chemistry, and, therefore, the applications of the superparamagnetic nanoparticles. These $\mathrm{Fe}_{3} \mathrm{O}_{4} @$ Chitosan nanoparticles are expected to be a useful support for enzyme. The ability of efficient separation from other molecules, such as products in the reaction system, and the reuse of the immobilized enzymes provide several advantages for its use as a catalyst in the industry. However, industrial-scale biotechnology and biorefinery processes require the development of low-cost and efficient magnetically responsive materials, as well as industrial-scale magnetic separators.

\section{Data Availability}

The datasets used to support this study are currently under embargo while the research findings are commercialized. Requests for data, 12 months after initial publication, will be considered by the corresponding author.

\section{Conflicts of Interest}

The authors declare that there is no conflict of interest regarding the publication of this paper.

\section{Acknowledgments}

The work in Mexico was funded by Consejo Nacional de Ciencia y Tecnología with MSc Grant 582097 and the Project CB-2014-241208. The work at ICMAB was supported by Ministerio de Economía y Competitividad (MINECO), Spain (CTQ2016-75150-R), and "Severo Ochoa" Program for Centers of Excellence in R\&D (SEV-2015-0496). The authors are grateful to the teamwork of Inorganic Materials \& Catalysis of the Institute of Materials Science of Barcelona (ICMAB-CSIC). The publication fee was funded by Programa para el Desarrollo Profesional Docente de la Secretaría de Educación Pública of Mexico.

\section{References}

[1] J. R. Venugopal and S. Ramakrishna, "Nanotechnology: 21st century revolution in restorative healthcare," Nanomedicine, vol. 11, no. 12, pp. 1511-1513, 2016.

[2] K. K. Kefeni, T. A. M. Msagati, and B. B. Mamba, "Ferrite nanoparticles: synthesis, characterisation and applications in electronic device," Materials Science and Engineering: B, vol. 215, pp. 37-55, 2017.

[3] F. Assa, H. Jafarizadeh-Malmiri, H. Ajamein et al., "A biotechnological perspective on the application of iron oxide nanoparticles," Nano Research, vol. 9, no. 8, pp. 2203-2225, 2016.

[4] F. Farjadian, S. Moradi, and M. Hosseini, “Thin chitosan films containing super-paramagnetic nanoparticles with contrasting capability in magnetic resonance imaging," Journal of Materials Science: Materials in Medicine, vol. 28, no. 3, pp. 47-49, 2017.

[5] W. Wu, C. Jiang, and V. A. L. Roy, "Recent progress in magnetic iron oxide-semiconductor composite nanomaterials as promising photocatalysts," Nanoscale, vol. 7, no. 1, pp. 3858, 2015.

[6] P. I. P. Soares, D. Machado, C. Laia et al., "Thermal and magnetic properties of chitosan-iron oxide nanoparticles," Carbohydrate Polymers, vol. 149, pp. 382-390, 2016.

[7] S. Karav, J. L. Cohen, D. Barile, and J. M. L. N. de Moura Bell, "Recent advances in immobilization strategies for glycosidases," Biotechnology Progress, vol. 33, no. 1, pp. 104-112, 2016.

[8] T. Honda, H. Yamaguchi, and M. Miyazaki, "Development of enzymatic reactions in miniaturized reactors," in Applied Bioengineering, pp. 99-166, Wiley-VCH Verlag GmbH \& Co. KGaA, Weinheim, Germany, 2017.

[9] Z. Al-Qodah, M. Al-Shannag, M. Al-Busoul, I. Penchev, and W. Orfali, "Immobilized enzymes bioreactors utilizing a 
magnetic field: a review," Biochemical Engineering Journal, vol. 121, pp. 94-106, 2017.

[10] M. I. Tokareva, M. N. Ivantsova, and M. A. Mironov, "Heterocycles of natural origin as non-toxic reagents for cross-linking of proteins and polysaccharides," Chemistry of Heterocyclic Compounds, vol. 53, no. 1, pp. 21-35, 2017.

[11] K. Meller, M. Szumski, and B. Buszewski, "Microfluidic reactors with immobilized enzymes-characterization, dividing, perspectives," Sensors and Actuators, B: Chemical, vol. 244, pp. 84-106, 2017.

[12] J. E. Hyeon, S. K. Shin, and S. O. Han, "Design of nanoscale enzyme complexes based on various scaffolding materials for biomass conversion and immobilization," Biotechnology Journal, vol. 11, no. 11, pp. 1386-1396, 2016.

[13] R. P. Vaz, L. R. de Souza Moreira, and E. X. Ferreira Filho, “An overview of holocellulose-degrading enzyme immobilization for use in bioethanol production," Journal of Molecular Catalysis B: Enzymatic, vol. 133, pp. 127-135, 2016.

[14] M. Nosuhi and A. Nezamzadeh-Ejhieh, "High catalytic activity of $\mathrm{Fe}(\mathrm{II})$-clinoptilolite nanoparticales for indirect voltammetric determination of dichromate: experimental design by response surface methodology (RSM)," Electrochimica Acta, vol. 223, pp. 47-62, 2017.

[15] A. Sahu, P. S. Badhe, R. Adivarekar, M. R. Ladole, and A. B. Pandit, "Synthesis of glycinamides using protease immobilized magnetic nanoparticles," Biotechnology Reports, vol. 12, pp. 13-25, 2016.

[16] M. M. Bradford, "A rapid and sensitive method for the quantitation of microgram quantities of protein utilizing the principle of protein-dye binding," Analytical Biochemistry, vol. 72, no. 1-2, pp. 248-254, 1976.

[17] L. Ge, Y. Xu, W. Liang, X. Li, D. Li, and C. Mu, "Short-range and long-range cross-linking effects of polygenipin on gelatin-based composite materials," Journal of Biomedical Materials Research Part A, vol. 104, no. 11, pp. 2712-2722, 2016.

[18] A. Azari, H. Gharibi, B. Kakavandi et al., "Magnetic adsorption separation process: an alternative method of mercury extracting from aqueous solution using modified chitosan coated $\mathrm{Fe}_{3} \mathrm{O}_{4}$ nanocomposites," Journal of Chemical Technology and Biotechnology, vol. 92, no. 1, pp. 188-200, 2017.

[19] H. Shokrollahi, "A review of the magnetic properties, synthesis methods and applications of maghemite," Journal of Magnetism and Magnetic Materials, vol. 426, pp. 74-81, 2017.

[20] S. Cao, P. Xu, Y. Ma et al., "Recent advances in immobilized enzymes on nanocarriers," Chinese Journal of Catalysis, vol. 37, no. 11, pp. 1814-1823, 2016.

[21] J. Sánchez-Ramírez, J. L. Martínez-Hernández, P. SeguraCeniceros et al., "Cellulases immobilization on chitosancoated magnetic nanoparticles: application for Agave atrovirens lignocellulosic biomass hydrolysis," Bioprocess and Biosystems Engineering, vol. 40, no. 1, pp. 9-22, 2017.

[22] P. P. Waifalkar, S. B. Parit, A. D. Chougale, S. C. Sahoo, P. S. Patil, and P. B. Patil, "Immobilization of invertase on chitosan coated $\gamma$ - $\mathrm{Fe}_{2} \mathrm{O}_{3}$ magnetic nanoparticles to facilitate magnetic separation," Journal of Colloid and Interface Science, vol. 482, pp. 159-164, 2016.

[23] I. M. Garnica-Palafox and F. M. Sánchez-Arévalo, "Influence of natural and synthetic crosslinking reagents on the structural and mechanical properties of chitosan-based hybrid hydrogels," Carbohydrate Polymers, vol. 151, pp. 1073-1081, 2016.
[24] P. I. P. Soares, A. I. Sousa, I. M. M. Ferreira, C. M. M. Novo, and J. P. Borges, "Towards the development of multifunctional chitosan-based iron oxide nanoparticles: optimization and modelling of doxorubicin release," Carbohydrate Polymers, vol. 153, pp. 212-221, 2016.

[25] J. Long, E. Xu, X. Li et al., "Effect of chitosan molecular weight on the formation of chitosan-pullulanase soluble complexes and their application in the immobilization of pullulanase onto $\mathrm{Fe}_{3} \mathrm{O}_{4}-\kappa$-carrageenan nanoparticles," Food Chemistry, vol. 202, pp. 49-58, 2016.

[26] R. A. A. Muzzarelli, M. El Mehtedi, C. Bottegoni, and A. Gigante, "Physical properties imparted by genipin to chitosan for tissue regeneration with human stem cells: a review," International Journal of Biological Macromolecules, vol. 93, Part B, pp. 1366-1381, 2016.

[27] J. Chen, J. Leng, X. Yang, L. Liao, L. Liu, and A. Xiao, "Enhanced performance of magnetic graphene oxideimmobilized laccase and its application for the decolorization of dyes," Molecules, vol. 22, no. 2, p. 221, 2017.

[28] C. Saikia, M. K. Das, A. Ramteke, and T. K. Maji, "Effect of crosslinker on drug delivery properties of curcumin loaded starch coated iron oxide nanoparticles," International Journal of Biological Macromolecules, vol. 93, Part A, pp. 1121-1132, 2016.

[29] N. A. Yazid, R. Barrena, and A. Sánchez, “The immobilisation of proteases produced by SSF onto functionalized magnetic nanoparticles: application in the hydrolysis of different protein sources," Journal of Molecular Catalysis B: Enzymatic, vol. 133, no. 1, pp. S230-S242, 2017.

[30] M. Martín, A. G. Orive, P. Lorenzo-Luis, A. H. Creus, J. L. González-Mora, and P. Salazar, "Quinone-rich poly(dopamine) magnetic nanoparticles for biosensor applications," Chemphyschem, vol. 15, no. 17, pp. 3742-3752, 2014. 


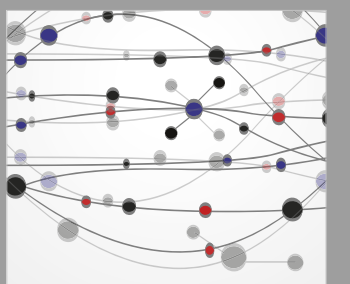

The Scientific World Journal
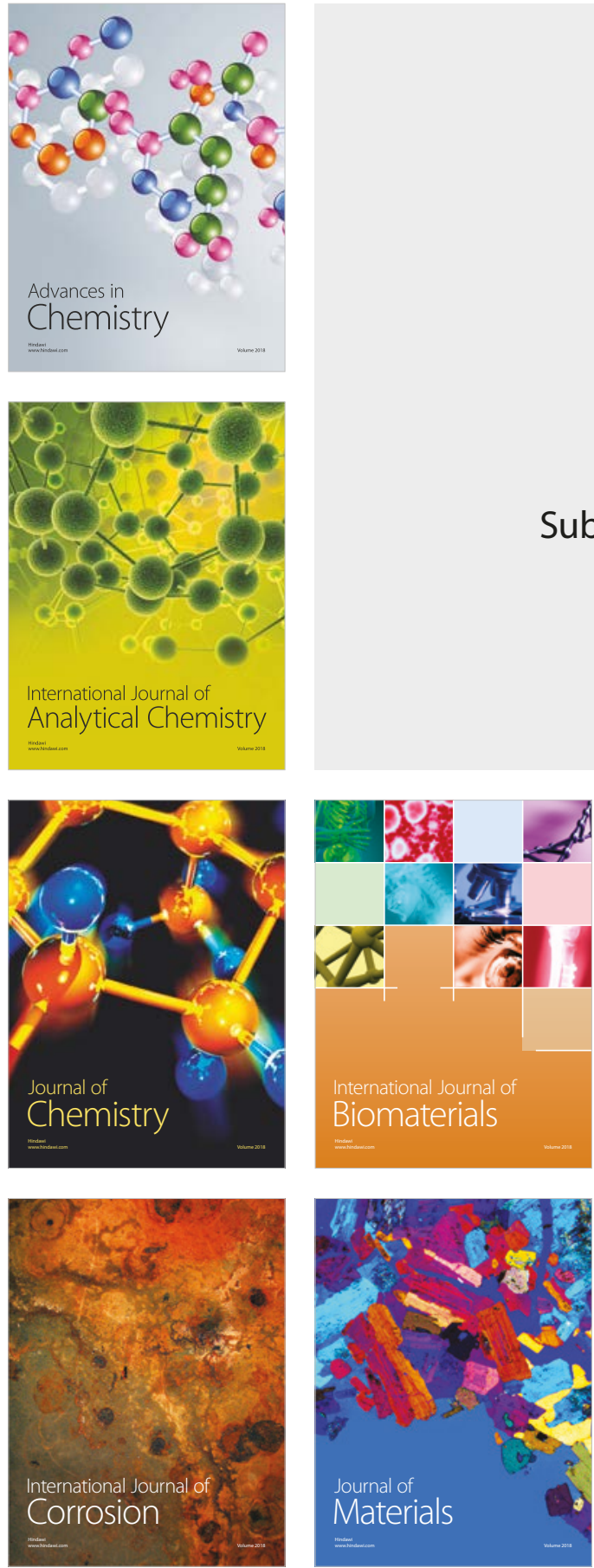

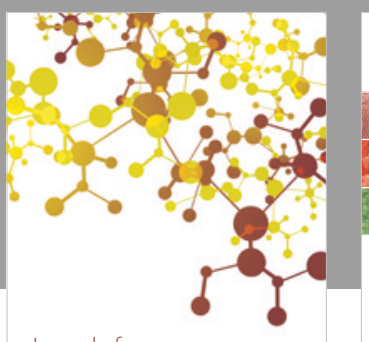

Journal of

Applied Chemistry
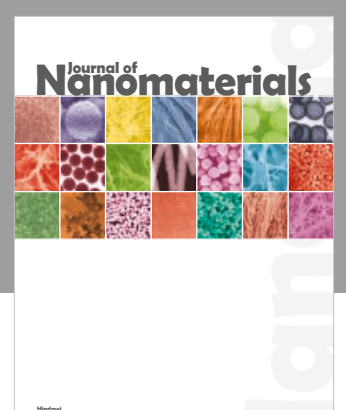

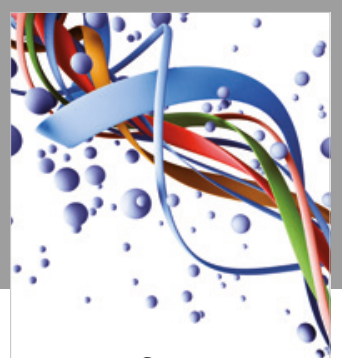

Scientifica

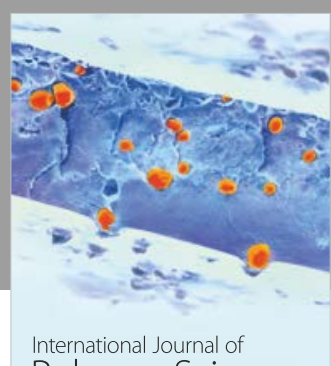

Polymer Science

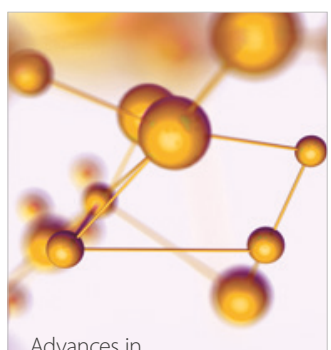

Physical Chemistry
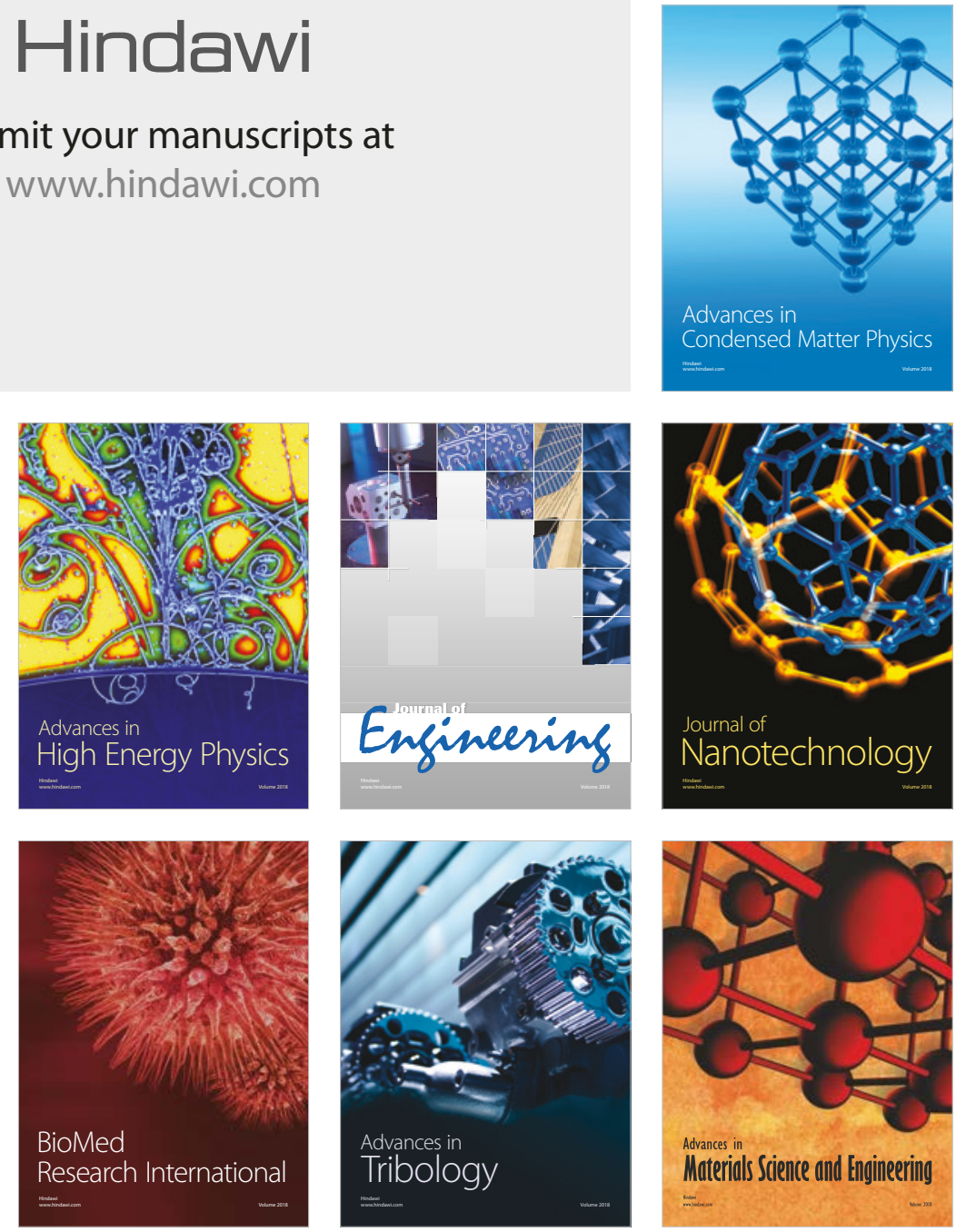